\title{
Language Planning In Zimbabwe: The Use of Indigenous Languages (Shona) As a Medium of Instruction in Primary Schools
}

\author{
Dr Ester Chivhanga ${ }^{1}, \mathrm{Mr}$ Sylod Chimhenga ${ }^{2}$, \\ ${ }^{I}$ Principal Lecturer, Department of Languages. United College of Education, Bulawayo, Zimbabwe \\ ${ }^{2}$ Lecturer/Student advisor, Centre for Student Management, Zimbabwe Open University, Zimbabwe
}

\begin{abstract}
The purpose of this study was to explore the effect of using indigenous languages in formal education in Zimbabwe. The study also investigated the opinions and attitudes of primary school teachers toward teaching science using an indigenous language. Qualitative data was collected using twenty classroom observations and interviews with ten purposely selected primary school teachers. Data were analysed using a thematic analysis. The findings revealed institutional and attitudinal barriers to using Shona as a language of instruction in Mathematics teaching and learning. The results also showed that some teachers frustrate and silence students' voices by preferring to use the English-only discourse in their teaching. When it came to using an indigenous language (Shona) as the only medium of instruction in teaching and learning, lack of learning materials, education language policies, attitudes of teachers and administrators were found to be barriers to the proposition. Changes in language policy, production of indigenous learning resources and transformation of teacher education curriculum were some of the recommended solutions required to promote indigenous languages as media of instruction for science education and schooling in general.
\end{abstract}

Keywords: language planning, medium of instruction, African language, language barriers,

Accepted Date: 01 July 2013

\section{Introduction And Background To The Study}

This paper focuses on the language planning in Zimbabwe with reference to the use of Indigenous Languages such as Shona in formal education. It focuses on how language planning in Zimbabwe has affected the development of African languages as mediums of instruction in the teaching and learning of different subjects in Zimbabwean schools. Language planning is a concept that is used to define both the process and study of language activities. It is a government authorised long term sustained conscious effort to alter a language itself or to change a language's function in a society for the purpose of solving communication problems (Chimhundu 1993).

Zimbabwe has attained independence more than three decades ago but there is no clear language policy. There has been no language planning debate as yet, but we have inherited British linguistic policies that derive from a colonial policy, which according to Mkanganwi (1992:9) emphasised on separate development for the different races, with a political counterpart in the theory and practice of indirect rule. English has continued to dominate the people's social, political and economic lives. It has not only dominated as the language of business, administration, politics and the media but also as the language of instruction in the entire education system. According to Chimhundu (1993:57) the "African languages continue to be downgraded in the schools and vernacularised outside in the community." This situation has been worsened by using English as the medium of instruction in the teaching and learning for the African languages yet the indigenous languages such as Shona and Ndebele are the right medium of instruction that ensure understanding and transfer of knowledge. African languages are not sufficiently developed to be used as the languages of science and technology.

This article highlights how language planning in Zimbabwe has affected the development of African languages with reference to their use as mediums of instruction in the teaching and learning of subjects in schools. It looks at the use of African languages as the best way of ensuring active participation of the populations in the activities of national life and in particular in the planning and management of the education system of Zimbabwe.

The important status of English globally undermines the status of African languages in the Zimbabwean education system. English as a high variety in Zimbabwe is used in business, commerce, 
parliament, and in schools as a medium of instruction. According to Kamwendo (1999: 229) "English is synonymous with the sound education whilst education through African languages is given second class rating."

English is a global language used in socio-economic, cultural and geo-political matters. African languages are low variety languages that are used at home and are acquired informally by members of the society. As a result the people relegate their African languages to a second-class status in comparison to English. The white and Indian population in Zimbabwe, as well as many Africans, tend to view knowledge of Shona or Ndebele as unnecessary for them. Even though it is official policy that these two African languages should be studied up to ' $\mathrm{O}$ ' level in the respective regions, many learners do not take this seriously as there is neither a reward nor sanction for obtaining a pass in these languages. English is the gateway into employment in both the public and private sector. They are forced to use English even if they would want to use African languages in situations where they would be more appropriate if they had equivalent technical terms. It is not surprising then that Language planners in Zimbabwe downgrade the use of African languages as mediums of instruction for different subjects in the education system. Zimbabwe has three national languages, Shona, Ndebele and English but virtually all children are educated through the medium of English and are expected to study their mother tongue as a subject. English is being promoted as a supra ethnic language of national integration. The low status accorded to the African languages adversely affects their use in the education system.

The need to consolidate Zimbabwe's political independence with linguistic independence has been enshrined in the claim by the Inter-African Bureau of Languages, a board accountable to the Organisation of African Unity, which conclusively puts it that " there are several advantages in using the mother-tongue as a medium of instruction: the development of critical powers, the fostering of effective communication, the enhancement of deeper cultural understanding and the increasing of national consciousness" (Chiwome and Thondhlana 1989:159). This line of thought has been reiterated in the National cultural policy and adopted by the Cabinet and Parliament of Zimbabwe in 1996 that "Zimbabwe's indigenous languages constitute a rich linguistic and cultural heritage for all Zimbabweans and should provide fertile ground for enhancing national understanding and national unity. Research will be carried out in indigenous language so that dictionaries, orthographies, textbooks, literary works as well as scientific and technological works are available in these languages. Priority will be given to those projects which enable these languages to be developed to a stage where they can be utilised at the highest educational levels so that they are able to effectively deal with all development issues. (Chimhundu 1998:40)"

In consonance with the above, language planning would be a desideratum for nation building, in order to develop and advance indigenous language for it to catch up with others in the modern world.

\section{Colonial Language Policies In Zimbabwe}

Language planning in this country started in 1920s as an activity consciously tailor made by missionaries who embarked on translating the Bible into African languages, in order to "reach the souls of Africans in the most effective way possible."(Roy-Campbell and Gwete 1997:22). The missionaries played a major role in the construction of what we have come to know as the Shona language.

The arrival of missionaries in the 16th Century in Zimbabwe saw the beginning of the writing of Shona language in different dialects. These missionaries set different missions in different areas of Zimbabwe. According to Dube (2002:8) and Chivhanga (2008) the initial writing in Shona in its various forms was done by different missionary societies in areas where Shona dialects were spoken. These missionaries had a lot of enthusiasm but little or no expertise in linguistic description. This created problems of orthographic differences within the same language, such as difference in choice of letters to mark sound spellings, word divisions and word choices. According to Kahari (1986:86) research into the nature and structure of the various dialects was conducted rather haphazardly at denominational levels by different missionaries. Men and woman who were involved in the study of these dialects worked independently and often without cooperation and coordination. Representations of the different missions, having failed in their own attempt to develop a common system of writing Shona, commissioned the South African linguist C M Doke, to undertake a dialect survey in 1929 and make suggestions about a common writing system. (Chimhundu 1992). In other words the purpose of his visit was to make a thorough survey of the language position throughout the country with a view to advising the Language planners of Government upon a uniform orthography and a possible unification of dialects, for the standardization of an official language for that part of the country inhabited by the Shona speaking people.

After the choice of the language to use, the missionaries worked in a more formal language planning by developing the African language's orthographies. This also included the decision on when to introduce English as a foreign language and to whom was also part of the language planning process during the colonial era. The colonial administration, however introduced their language as the linguistic tool of administration and power. African languages were considered inadequate for administrative purposes. The mother tongue was used in lower primary school. English was the passport to better opportunities. 
The official mechanism of handling languages in colonial Zimbabwe was marked by three stages. Between 1903-1928 the Southern Rhodesian Missionary Conference handled language issue. In 1929 Doke began his study of how to unify Shona language. This resulted in the Doke report of 1931. (Magwa 2003:22).

One of Doke 's recommendations was the formation of the Language Advisory Committee for Shona and for Ndebele. These committees were to monitor the language scene and make recommendations to the government of the day. It is in the interest of this research to investigate how these Advisory Committees contributed to the marginalisation of African languages in their use in the formal education system of Zimbabwe.

The advisory committees were later changed into language committees that did not have power to set rules but were there to advise the Ministry of Education on issues related to the language. They were a loose structure of individuals who were brought together from time to time. They focused on orthographies, producing dictionaries and development of literature. Until the monolingual Shona dictionary, produced by the African Languages Lexical Project based at the University of Zimbabwe, all the dictionaries were produced by Europeans for Africans.

\section{Post-Language Policies In Zimbabwe}

Since independence in 1980 Zimbabwe does not have an Official Language Policy Document that specifically focuses on the use African Languages as languages of instruction(Hadabe1996). The legal status of language in Zimbabwe is stipulated in the 1987 Education Act. It states that "English is the official language and Shona and Ndebele are national languages with restricted official use." (Roy-Campbell and Gwete 1983:208). The UNESCO Regional Office for Education in Africa defines official language and national language as follows: 'Official Language: a language that is used for government business and other formal purposes within a country, e.g. English, French or an African language like Swahili. National language: maybe an African Language that is also an official language, or a language that has been decreed to be a National language of a country. (Mkanganwi1992:10)'

In addition, five of the minority languages are recognised by the Zimbabwean government. The education language policy as enunciated by the Education Act 1987 (as amended in 1996) states that:

1. Subject to the provisions of this section, the three languages of Zimbabwe, namely, Shona, Ndebele and English shall be taught in all primary schools from the first grade as follows:

(a) Shona and English in all areas where the mother tongue of the majority of the residents is Shona or

(b) Ndebele and English in all areas where the majority of the residents is Ndebele.

(2) Prior to the fourth grade, either one of the languages referred to in paragraph (a) or (b) of subsection (1) may be used as the medium of instruction, depending upon which language is more commonly spoken and better understood by pupils.

(3) From the fourth grade, English shall be the medium of instruction provided that Shona and Ndebele shall be taught as subjects on an equal time allocation as the English language.

(4) In areas where minority languages exist, the Minister of Education may authorise the teaching of such languages in primary schools in addition to those specified in subsection (1), (2) and (3) (PartX1 Section 55 page 255).

As shown above, although all the major languages enjoy some degree of prominence under the Act, English continues to enjoy the central role as indicated in subsection (3) in the non-obligatory nature of the early primary school mother tongue instruction. This recognition is largely in word only. According to Thondhlana (2005:33) in Zimbabwe most secondary schools prefer to use English as a medium of instruction from the outset to ensure their students' proficiency in English, which is considered the language of power and economic well being than the African languages. None of Zimbabwe's indigenous languages is a medium of instruction beyond the fourth grade.

According to Hadebe (1996), it is not clear whether the minority African languages co-exist with the national languages Shona and Ndebele or they are the sole African languages in their respective areas. The Education Act 1987 does not give the impression that the areas where minority languages are spoken are should be specified.

Choosing a language or a group of languages for specific functions in a country has far reaching implications on the status of that language or group of language. (Hadebe1996). Ngugi wa Thiongo (1981:4) stated " the choice and use to which language is put is central to a people's definition of themselves in relation to their natural and social environment, indeed in relation to the entire universe." The choice has implications for the educational system as well as on the economics of language promotion. Each language to be taught must serve a purpose otherwise there would be no justification for human, material and financial resources expended on teaching a language for its sake. The difficulty lies in specifying which language does what. This results in ambiguously worded policy statements as noted by Bamgbose that:

Language policies in African countries are

characterised by one or more of the 
following problems; avoidance, vagueness, arbitrariness, fluctuations and declaration without implementation. (Bamgbose 1991:111)

The characteristics best describes Zimbabwe's policy towards African Languages.

In our education system in Zimbabwe we chose English for operational efficiency and nationalistic goals as most African states perceive languages of wider communication to be neutral. Ndebele and Shona were obviously presumed to be serving nationalistic priorities. There, English, Shona and Ndebele are serving the socio-political and educational functions in Zimbabwe.

After independence, English continued to dominate in both the electronic and print media. Shona is not being used in the Internet, media, medicine etc. In tertiary education and secondary schools, English trained teachers outnumber the Shona trained teachers. This has encouraged the development of English as a language and disadvantaged the development of African languages such as Shona and compelling teachers and learners of Shona to look down upon their language. In fact, English has established itself in domains such as administration, education, jurisdiction and other government controlled and non-governmental institutions to the extent that it has become a major impediment, a brake or constraint on the promotion and development of African languages (such as Shona) as argued by Mutasa (2003).

Chiwome and Thondhlana (1992) investigated the teaching and learning of Shona through the medium of Shona and English at High School and University levels. Their premise was that using English as the language of learning and teaching puts non-English speaking students at a disadvantage. They established that although the subjects have an African language at heart they preferred to be taught in English especially at University (Mutasa 2003). The use of both English and Shona in one lesson, that is code switching, would definitely undermine the image of Shona as an African language. Their research did not specifically look into the issue as to whether African languages can be used in the teaching of subjects such as Science and other technical subjects.

In their research Gudhlanga and Makaudze (2005) argue that the marginalisation and down grading of African Languages are as a result of colonial language policies. They argued that during the colonial period students were forced to use English in the teaching and learning situation of Shona and Ndebele. Those caught speaking an African Language were severely punished and in such cases Africans had no choice but to learn the language of the colonial master. Shona was introduced as a subject at ' $O$ ' level in 1957 and Ndebele in 1967 for African schools. In former Group A schools Shona was introduced in 1964 and Zulu instead of Ndebele in 1979. Unqualified personnel taught the indigenous languages when they were introduced in schools (Chiwome 1996). To make matters even worse the time slots allocated for instruction of indigenous languages was unfavourable. Shona and Ndebele were usually allocated time in the afternoon when it was quite hot and learners were tired, (Bamgbose1991). The prime teaching period in

The morning was usually allocated to the teaching of Mathematics and English that were considered important. Also parents and teachers wanted their children to pass English and this led to social stratification that undermined the unity of the indigenous people. Mutasa (2003:304 ) supports the notion that" parents perceive English as the answer to their and their children's problems in that at present, unquestionably English is the gateway to success socially, politically and economically". Chimhundu (1993: 58) observed that in the post colonial era we have in Zimbabwe an unbalanced bicultural and bilingual situation in which the $\mathrm{H}$ or high status language is the official language of the former colonial power, while the indigenous languages are of $\mathrm{L}$ or Low status languages. This means that African languages such as Shona and Ndebele are looked down upon as less important socially and culturally in Zimbabwean secondary schools. It is of interest in this research to investigate the Language planning in Zimbabwe with reference to the use of African languages in the teaching and learning of subjects in the Zimbabwe education system.

During colonial Rhodesia (now Zimbabwe) "the belief that English was a superior language to Shona (African language) was certainly there (Ngara 1982:24)". After independence these attitudes continued but most of the school children were conscientized to appreciate their own cultures and languages. According to Dube (1997:11) these attitudes may have improved at independence but now it would appear they are contributing to the marginalisation of African languages such as Shona and Ndebele in their use as languages of instruction in Zimbabwean formal education.

\section{Status Language Planning In Zimbabwe}

In Zimbabwe status language planning has involved designating official and national languages and making provisions for the use of several minority languages in education and the media.(Roy-Campbell and Gwete(1983:216). This has been done through the legal instrument of the Education Act 1987. The Government of Zimbabwe is the body that has made decisions about language usage in the education system of the nation. According to Viriri (2003) a detailed sociolinguistic survey of language use in Zimbabwe needs to be done to provide a clear picture of the current sociolinguistic reality in Zimbabwe. The survey should include attitudinal 
information, views of the different sections of the population about language use preferences, bilingualism and relationship with other languages, language of instruction, and the importance of English in their live. It is the intention of this research to find how African languages could be used as languages of instruction in the subjects being taught in Zimbabwean schools.

\section{Corpus Laguage Planning In Zimbabwe}

The National Language Committees have been involved in corpus planning in Zimbabwe ways in which African languages could be sufficiently developed in order to be used as the languages of science and technology in the education systems of the modern world, since the colonial period and have persisted into independent Zimbabwe. The composition of the national languages committees in independent Zimbabwe includes: the Head of Department of African languages at the University of Zimbabwe; Ministry of Education Personnel; Heads of Divisions, subject panels and the Zimbabwe school Examination Council; Zimbabwe Council of Churches, publishers, Zimbabwe Broadcasting Corporation, the literature Bureau, the Head of Curriculum Development Unit, editors of print media. In addition to the Shona and Ndebele Committees there is also a Minority Language Committee.

The most recent effort in corpus planning for Zimbabwean languages has been the African Languages lexical (ALLEX) Project that is based at the University of Zimbabwe in the Department of African Languages and Literature. This project completed a monolingual Shona dictionary, Duramanzwi re Chishona in 1996. The ALLEX project is the first effort by mother tongue speakers of Shona and Ndebele to engage in systematic corpus planning.

\section{Research Problem}

The lack of proper language planning in Zimbabwe has downgraded and marginalized the use of African language in formal education. Shona and Ndebele in their present state, as national languages, are underdeveloped and are inadequate as national languages of instruction in formal education. These African Languages are not sufficiently developed to be used as the languages of science and technology. There are no textbooks, dictionaries in the indigenous languages for use in other school subjects. The underdevelopment of African Languages has forced teachers and learners to use English where it would have been to their advantage to use African Languages Shona and Ndebele have been declared as national languages in Zimbabwe but one wonders, with such inadequacies as mentioned above, how it would be possible to use them as languages of instruction in different subjects of our education curricula.

\subsection{Procedure}

\section{Methodology}

Questionnaires were administered to collect data from the Language Committee members, Editors, Publishers, Educationists, Shona teachers in primary schools. The questionnaires were administered to 5 editors, 5 publishers and to 50 primary school teachers, who are teaching Shona in schools and other tertiary institutions. Interviews with selected Shona writers were carried out.

Qualitative data was collected using classroom observations and interviews with ten purposely selected rural primary school teachers. Twenty classroom observations were conducted and video recorded. The observations focused on classroom communication and interactions between the teachers and their students and amongst students themselves. The questions that were designed for the interviews focused on the teachers' experiences in teaching mathematics using English as a medium of instruction as well as their attitude towards using an indigenous language, Shona, as a medium of instruction in teaching mathematics.

\subsection{Analysis of Findings}

The qualitative data collected during classroom observations were video-recorded, while the interviews were audio-taped. The data were later transcribed, and analysed using thematic content analysis. The observations were analysed for student teacher interactions, student-student interactions and the language used in the teaching and learning of mathematics. Interviews with teachers were analysed for, belief, views and attitude toward the use of English and Shona in the teaching and learning of mathematics.

\section{Results And Discussions}

The success of using Shona as a medium of instruction in the teaching of Mathematics in primary schools depends on people's attitudes and will to actually implement it. Language attitudes are best appreciated by closely examining their origin. An attitude is an organized predisposition to think, feel, perceive, and behave toward referent or cognitive object an enduring structure of beliefs that predisposes the individual to behave selectively toward attitude referent (Kerlinger, 1986: 453; Kosslyn and Rosenberg, 2006: 738). In short, an attitude is a disposition to respond favourably or unfavourably towards an object, person, institution or event. 
Attitudes locate objects of thought on dimensions of judgment (McGuire, 1985 in Lindzey and Aronson, 1985). Such a disposition can be towards language (referent object) that may be viewed favourably or unfavourably.

An attitude is in fact a belief that forms a capacity that is directed towards certain aspects in human life. Attitudes are thus, "organizations of beliefs about things out there" (Kerlinger, 1986: 456) that predispose individuals to behave or respond in a certain manner towards an attitude object. Attitudes take a positive or negative direction with very few cases being neutral (Kosslyn and Rosenberg, 2006). Since attitudes to language form a belief (in individuals) in relation to the referent object, their effect on language policy change cannot be taken for granted since they play an important role leading to either acceptance or perspective of the parents rejection of language policy change. It is imperative that language attitudes of users be taken into account before change in the language of instruction is effected.

There are several significant questions that asked of the respondent to provide answers which showed their attitudes towards the use of Shona as medium of instruction in education from the perspective of parents, teachers/lecturers and learners. One of them was: Which language(s) is mostly likely to give you power and prestige in Zimbabwe if you speak it?

The teachers, editors and publishers indicated on the questionnaire that English was the language of power and prestige in Zimbabwe and that English is the official language of instruction in the education system of Zimbabwe. Hence, English dominates other African languages as evidenced by the responses of the parents, editors, teachers and publishers. One of the reasons that these respondents opted for English was that one becomes globally marketable in industry and commerce. Such a view would not support the use of Shona as a language of instruction in education. Views that English is more important than Shona have been passed on to children by parents who tell children that English is prestigious and provides educational and employment opportunities in the future (Nondo, 1996). The children develop negative attitudes towards the indigenous languages which they regard as less important (Adegbija, 1994)

Another significant question on attitudes from the interviews was: What do you think is the attitude of Zimbabweans towards mother tongue instruction? The respondents to this question believe that most of the Zimbabweans would prefer English as the medium of instruction in education. Most interviewees felt that English offers them better opportunities for employment compared to Shona. However, English was seen as empowering them to compete well in the global village. English guarantees them "access to the system and equal opportunity to participate in it" (Adegbija, 1994: 3). As such, changing to indigenous languages such as Shona is viewed as a direct threat to their (respondents) perceived job opportunities, thus attracting negative attitudes. The aforementioned observations led to the conclusion that language attitudes of users, whether cognitive, affective or behavioural, matter much in language planning. Unless and until attitudes change favourably towards the proposed language, users will continue to reject the intended language innovation.

In the then Rhodesia (colonized Zimbabwe), the colonialists legislated English language as the only medium of instruction in schools. The chain reaction leading to the subsequent dominance of English in the school curriculum was set off in 1903 following the first education ordinance (Atkinson, 1972). Through a subtle tutelage Africans in Zimbabwe came to regard English, and indeed associate it with knowledge, goodness, sweetness and an array of other positives. Those who could speak it received commendation and were made to feel that they were far better than those who could not speak it. For most Africans, English became synonymous with knowledge and education. Speaking good English was, wrongly of course, seen as an indicator that one was educated. English was thus, associated with good life and as such, attitudes towards it became favourable. Those unable to speak English were regarded as backward.

Rwambiwa (1996), Gatawa (1998) and Gudhlanga (2005) attribute the negative attitudes towards the use of African languages as languages of instruction in education, to the fact that the current language policy requires children to learn in the mother tongue only in the lower grades. Children will eventually have to learn in English and will be required to pass English as a subject in order to obtain a full "O" level certificate. According to Chivhanga (2008), the emphasis on passing English at ' $O$ ' level adversely affects the interest of students in studying Shona as a subject. As a result Shona students view English as a gateway to success and considered Shona as a language that is not economically viable.

\section{Benefits Of Using Shona As A Medium Of Instruction.}

Advocates for the use of mother-tongue education view the continued use of the former colonizer's language as an attempt to "remain fixed on the false premise that their indigenous languages are useless as vehicles of instruction in science and technology" (Rwambiwa, 1996: 1). The respondents indicated that the use of Shona as a language of instruction, that is, mother tongue instruction, in education has societal benefits in Zimbabwe. The mother tongue forms the basis of learning because mother tongue instruction facilitates understanding. The respondents agreed that the use of Shona as a language of instruction in education will benefit the society. Language is a communication tool without which there is no development. It is a vehicle of projecting one's norms, values, beliefs, thought processes and these need to be communicated. 
Economic growth can be achieved through communication and interaction of different socio-economic factors. Using Shona as a language of instruction in education will benefit the majority of the population as it is spoken by more than $80 \%$ of Zimbabwe's population. Education would become accessible to many. English medium restricts learners' performance. Learning becomes easier if concepts are taught in one's mother tongue. The mother tongue forms the basis of learning because mother tongue instruction facilitates understanding. Mother tongue accelerates learning and injects pride and independence. The use of Shona, the mother tongue, respondents from both the questionnaire and the interview strongly agreed that it will further promote better understanding between the home and the school. This conclusion is supported by Mavesera (2009) who also concluded that participants in her study also stressed emphatically that learning in general occurs more effectively if the required cognitive development is taking place through the use of a first language as a language of learning. If Zimbabweans would want to make strides in both educational and economic development, children should actively participate using indigenous languages in the development of science and technology.

Employment of Shona in education ensures rejuvenation and revitalisation of African Languages and enhances their image when people realise that concepts and subjects formally reserved for English can be taught in Shona too. This also enables environmental adaptation by sharing ideas to manage or conquer the environment. Shona, as a mother tongue, is undoubtedly the language through which the child will understand his/her environment and concepts far better (Mutasa 2004). Use of Shona will provide access to almost all sources of knowledge including school textbooks. This may lead to the promotion or better status for indigenous languages.

From the study there were respondents who felt that no much benefit would be experienced if Shona is used as a language of instruction in education. Some felt that the use of Shona would create learning problems as it has limited terminology and vocabulary to scientific and educational concepts. They argue that instruction in Shona will only benefit speakers of that language variety at the expense of the wider African community. African communities will be isolated and excluded from the global village, which communicates mainly in internationally recognized languages such as English. It would create communication problems between Zimbabwe and other nations on the African continent and beyond. One has to note that even where the language innovation is likely to benefit users if people do not view it as such they are unlikely to support the language change because it would suffer from tissue rejection. In cases where the language attitudes are negative, measures ought to be taken to encourage users to develop positive attitudes towards the proposed language.

Findings from the interviews and questionnaires show that employment of Shona in education ensures rejuvenation and revitalisation of African Languages and enhances their image when people realise that concepts and subjects formally reserved for English can also be taught in Shona. This also enables easy environmental adaptation by people through sharing ideas of managing. Shona, as a mother tongue, is undoubtedly the language through which the child will understand his/her environment and concepts far better (Mutasa 2004). Use of Shona will provide access to almost all sources of knowledge including school textbooks

From the interview participants it is evident that language is a vehicle of communication that enhances development within the society. Economic growth can be achieved through communication and interaction of different socio-economic factors. It is in these indigenous languages that knowledge for the improvement of the masses of the Zimbabwean society can be transmitted. A language of instruction, such as Shona, which is the home language or mother tongue, is an instrument for the cultural and scientific empowerment of people. Cultural freedom and African emancipation therefore cannot be cultivated expanded or developed where the language of instruction is different from the home language or the language people normally speak in their everyday lives (Mavesera 2009)

\section{Conclusions}

English is prestigious and provides educational and employment opportunities in the future and that one becomes globally marketable in industry and commerce. English is the language of power and prestige in Zimbabwe and that English is the official language of instruction in the education system of Zimbabwe. Language attitudes of users, whether cognitive, affective or behavioural, matter much in language planning. Unless and until attitudes change favourably towards the proposed language, users will continue to reject the intended language innovation. There is need for the Government to formulate a clearly defined language policy whereby Shona is given equal treatment with English. Currently the Government has its language policy through the provision of the Education Act of 1987(revised in 1996) and this is failing to enforce the use of African languages as media of instruction in teaching science subjects like mathematics.

\section{References}

[1]. Adegbija, E. 1994. Language attitudes in sub-Saharan Africa: A sociolinguistic overview. Clavedon: Multilingual Matters Ltd.

[2]. Atkinson N (1972). Educational Co-operation in the Commonwealth: An Historical Study. Series in Education. Occasional Paper No. 1 (1972). Salisbury: University of Rhodesia, p. 265. 
[3]. Bamgbose, A. 1991. Language and the Nation: The language question in sub- saharan Africa. Edinburg: Edinburg University Press.

[4]. Chimhundu, H. 1992. 'Standard Shona Myth and Reality' in Democratically speaking International Perspectives on language Planning, Vigel, T. Crawhall (editor). National Language Project, Salt River. 7924. Republic of South Africa.

[5]. Chimhundu, H. 1993.'The status of African Languages in Zimbabwe'. SAPEM,_October 1993, 57-59.

[6]. Chimhundu, H. 1998. 'Keynote address of the Zimbabwe delegation to the experts meeting of the intergovernmental Conference on African Language policies.’ Harare: March 17-21. Chivhanga, E. 2008

[7]. The diglossic relationship between Shona and English languages in Zimbabwean secondary schools. Pretoria: Unisa

[8]. Chiwome, E. M. $1996 . \quad$ A social History of the Shona Novel. Effel Flats: Juta Zimbabwe Pvt Ltd.

[9]. Chiwome E. M.\& Thondhalana J. 1992. 'Sociolinguistics and education: a survey concerning attitudes on the teaching of Shona through the media of shona and English.' In R. K. Herbert (ed) Language and Society in Africa. (P247-263) Cape town: South Africa.

[10]. Chiwome E. M.\& Thondhalana J. 1989. 'The teaching of Shona through the medium of Shona and English in High schools and at the University of Zimbabwe.' In Zambezia, 1989 xvi(ii).

[11]. Dube, S. 1997. A study into reasons why Shona as the low variety in a diglossic relationship with English in postindependent Zimbabwe. Unpublished Article submitted to the Department of African Languages and Literature at Unisa.

[12]. Dube, S. 2000 An investigation of the current Shona orthography: effects of its limitations and suggested solutions. Unpublished dissertation for MA, Pretoria : University of South Africa.

[13]. Gatawa, B.S.M. 1998. Quality - Quantity Dilemma in Education: The Zimbabwean Experience. Gweru: Mambo Press

[14]. Government of Zimbabwe 1987. Zimbabwean Education Act. Harare: Government Printers.

[15]. Gudhlanga, E. S. and Makaudze, G. 2005. 'Promoting the use of African Languages as a medium of instruction of Higher learning in Zimbabwe: the case of MASU's Department of languages, literature and Music.' Paper presented at University of KwaZulu Natal. Durban: 27-29 June 2005.

[16]. Gudhlanga, E. S. 2005. 'Promoting the use and teaching of African Languages inNZimbabwe.' In ZJER 17 No. 1 pp 54-66. Education Inc, p. 738

[17]. Kahari, G $1986 \quad$ Aspects of the Shona Novel. Gweru: Mambo Press.

[18]. Kamwendo, G. H. 1999. 'The political dimension of mother tongue instruction in Malawi.' In Limage L. (ed) Comparative perspectives on language and literacy. Dakar: Unesco- Braeda.

[19]. Kerlinger FN 1986. Foundations of Behavioural Research (3rd ed). New York: Holt, Rinehart and Winston, pp. $453-456$.

[20]. Kosslyn SM, Rosenberg, R. S. 2006. Psychology in Context (3rd eds). New Delhi:

[21]. Magwa, W. 2003. A unified standard orthography for Shona Language varieties (Botswana, Mazambique and Zimbabwe). Capetown: SED Printing Solutions

[22]. Mavesera, M. 2009 Empowerment through language: exploring possibility of using African languages and literature to promote socio-cultural and economic development in Zimbabwe, Unpublished Thesis, Pretoria: Unisa

[23]. 'Mkanganwi, K. G. 1992 'Language Planning in Southern Africa' in Democratically speaking International Perspectives on language Planning, Vigel, T. Crawhall (editor). National Language Project, Salt River. Republic of South Africa.

[24]. Mutasa, D. E. 2003.The Language policy of S. A.: What do people say? Pretoria : Unisa.

[25]. Ngara, E. A. 1982. Bilingualism Language Contact and Planning, Proposals for Language use and Language Teaching in Zimbabwe. Gweru: Mambo

[26]. Nondo, S. J. 1996. The main problems faced by students whose mother tongue are other Zimbabwean African languages in learning Ndebele. University of Zimbabwe, Unpublished.

[27]. Roy-Campbell, Z.M. and Qorro, M. 1998. Language crisis in Tanzania: The myth of KiSwahili versus English. Dar es Salaam: Mkuki na Nyota

[28]. Thondhlana, J. 2005. 'Languages for teaching Using indigenous and learning in Zimbabwe' http://jan.ucc.nau.edu/ jar/ILAC/ILAC_4pdf (accessed 26 November 2006)

[29]. Viriri,V. 2003. 'Language planning: the conservation and management of indigenous languages in Zimbabwe.' Paper presented at ICOMOS 14th General Assembly and Scientific Symposium 